\title{
Genetic and morphologic characteristics of the gigantic mutant of oats, Avena sativa L.
}

\author{
Hannu Ahokas \\ Department of Genetics, University of Helsinki, 00100 Helsinki
}

\begin{abstract}
A gigantic mutant (gig-a) isolated from cv. Hannes is described. The mutant is lush, many-noded and late ripening not reaching, maturity during our growing season. It does not respond to cold vernalization, application of gibberellins or 12/12 photoperiod by the non-mutant phenocopy. There was no genetic complementation by the infection of Ustilago avenae (Pers.) Rosb. Results are presented showing that the mutant responds to seasonal and other environmental conditions to a greater extent than the non-mutant. Several characteristics of the mutant are compared with those of $\mathrm{cv}$. Hannes and the $\mathrm{F}_{1}$ generation of the backcross. The inheritance is monofactorially recessive. The $\mathrm{F}_{1}$ plants display a great heterosis of grain production. Evidence is presented regarding the temporary heterozygote advantage as the cause of the retention of the mutant in oat stands.
\end{abstract}

The late-maturing, gigantic mutants of the common oats are easily observed even by a layman at harvest time. By that time, the broad-leafed (up to 4.5 $\mathrm{cm})$, green mutants are only at the vegetative stage. A mutant plant is especially easy to detect when the normal oats remain low, for instance due to an early summer drought. Being very late, none of the mutant plants seed in Finland, but are selected away from the seed crop every year. Nevertheless, the mutants can be considered to be very common in some seasons (KIVI 1968). This condition is presumably attained by either (1) a segregation of the previous year's overdominant heterozygotes, or (2) this impression may be due to an exceptionally good exposure of the mutants from the rest of the stand owing to seasonal factors favourable to the growth of the mutant. The first hypothesis is discussed in this paper.

The present mutant line designated by the name HA 68-2 was established from a single plant of cv. Hannes in 1968. Since very little has been reported about the inheritance of the gigantic oats, HA $68-2$ was tried as backcross to Hannes. This proved difficult, however resulting only in a few seeds during the two seasons the cross was attempted.

ZILLINSKY (1959) describes a'monster' mutant in oats, which is very similar to the gigantic ones. His report is apparently the only one about the inheritance of this type of oat mutants. 


\section{Material and methods}

1. Plants and mutant symbols

HA 68-2 was crossed with plants chosen at random of the original variety Hannes, which was of a commercial origin. In the crosses of 1970 , the genomes of at least four different Hannes plants were involved. A line established from these plants was arbitrarily designated by the name Hannes-1. This line was used in the crosses of 1972 , and serves as the standard.

The present type of oat mutants is generally referred to as gigantic. The symbol gig is now introduced. In the text, the respective symbol for the nonmutant allele will be Gig. The phenotypes are marked by the symbols in parentheses, (gig) for the mutant, and (Gig) for the normal phenotype. Since several gig mutants have been isolated, the defined symbol gig- $a$ is reserved for the one in HA $68-2$.

The seed collected from $F_{1}$ plants is designated by $\left.F_{(2}\right)$, that from $F_{2}$ plants $\mathrm{F}\left({ }_{3}\right)$, and so on.

\section{Pot experiment}

A pot experiment with HA 68-2 and Hannes -1 was performed using Rauneberg $19 \mathrm{~B}$ brown plastic pots $(\varnothing 19 \mathrm{~cm})$ with six plants per pot. Two types of soil were used: (1) Easily panining, silty clay, low in humus $(3.8 \%)$ and nutrient content (total N 1778, P 7.2, K 250, and $\mathrm{Ca} 1400 \mathrm{mg} / \mathrm{l} ; \mathrm{pH} 5.9$, conductivity 2.0). (2) A 1: 1 mixture of silt and compost (humus $10.4 \%$; total N 4391, P 68, K 364, Ca $4625 \mathrm{mg} / \mathrm{l}$; pH 6.7, conductivity 3.3).

Three water levels were applied: (1) 40 , (2) 80 , and (3) $120 \mathrm{ml}$ as the daily mean. The lowest water level was subjected to a considerable water stress. The well-water used was sampled once, and found to contain total N 1.54, $\mathrm{P}$ lower than $0.01, \mathrm{~K} 0.65$, and $\mathrm{Ca} 1.1 \mathrm{mg} / \mathrm{l}$, with $\mathrm{pH}$ 6.1. Natural precipitation was prevented with a plastic roof above the pot bed.

A trial of three nitrogen levels was performed. The medium water level $(80 \mathrm{ml})$ was taken as the control or 0 level. The additional nitrogen, $\mathbf{N} 4.8$ or $19.2 \mathrm{mg}$ as the daily mean, was given as an equimolar mixture of $\mathrm{Ca}\left(\mathrm{NO}_{3}\right)_{2}$, and $\mathrm{NH}_{4} \mathrm{NO}_{3}$..

Each treatment was replicated in three pots randomized within the soil blocks. The pots contained only one of the genotypes since the possible root grafting of different genotypes might cause errors.

\section{Cold and gibberellin vernalization. Infection with Ustilago}

Dehulled, surface sterilized $\left(0.05 \% \mathrm{HgCl}_{2}\right.$ for $\left.20 \mathrm{~min}\right)$ seeds were laid on sterile filter paper in Petri dishes, and kept for 60 days at $4-5^{\circ} \mathrm{C}$. For the control, seeds were germinated at room temperature to match the germination stage of the cold treated germinants. The cold treatment was sufficent to induce earing in the Finnish winter wheat cv. Elo.

Each of the three gibberellins, $\mathrm{GA}_{1}, \mathrm{GA}_{4}$, and $\mathrm{GA}_{7}$, were applied in a $2 \mathrm{mM}$ methanol solution. Small droplets from a hypodermic syringe were allowed 
to run on the expanded leaves. Each of the 3-5 -leafed seedlings received $0.01 \mu \mathrm{M}$ of gibberellin. The control was treated only with methanol.

Dehulled kernels were wetted for 36 hours after which they were dusted with the teliospores from a panicle infected with Ustilago avenae (Pers.) Rostr. The germinants were planted in the field on the following day. The uninfected plants served as the control.

\section{Growing of $F_{1}$ generation}

In 1971, five seeds of each, Hannes, HA $68-2$, and $F\left({ }_{1}\right)$ were grown on hills, $0.5 \mathrm{~m}$ apart with an $1 \mathrm{~m}$ plantless space around. They were seeded on the $17^{\text {th }}$ of May.

In 1973, twenty seeds of Hannes-1, and HA 68-2, and seven $F\left({ }_{1}\right)$ seeds of the cross HA 68-2 (o) $\times$ Hannes-1 were seeded in $4 \times 4 \mathrm{~cm}$ peat pots on the 19th of May. Ten days later, the seedlings were provided with a code, and transplanted in the field in a randomized sequence in five rows $30 \mathrm{~cm}$ apart, with a $30 \mathrm{~cm}$ interplant distance.

\section{Growing of $\mathrm{F}_{2}$ generation at different densities}

In 1972 , two $\mathrm{F}_{1}$ plant progenies of the cross Hannes (ㅇ) $\times \mathrm{HA} 68-2$, and three of the reciprocal combination were grown in $2 \mathrm{~m}$ long rows. The ransdomized sequence of the progeny rows was follewed in three blocks, each containing four rows of both the reciprocal crosses. The blocks were grown side by side. The seeding density varied from block to block, the intrarow $x$ interrow distances being:

$$
\begin{aligned}
& 2 \times 10 \mathrm{~cm} \\
& 4 \times 17.5 \mathrm{~cm} \\
& 8 \times 25 \mathrm{~cm}
\end{aligned}
$$

When scored at the twoleafed stage, the emergence was $89.8 \%$, there being no significant difference between the blocks $\left(\chi^{2}=0.112 ;\right.$ d.f. $\left.=2 ; \mathrm{P}>0.90\right)$.

The $\left.\mathrm{F}_{3}\right)$ seed was taken from the inner parts of the blocks. The plants at row ends and side rows were discarded. All the seed of the sampled plants was taken. The samples involved only the (Gig) phenotypes, while the homozygous mutants were discarded.

\section{Growing of $\mathrm{F}_{3}$ fraction}

In 1973, the $\mathrm{F}_{3}$ fraction were grown to test the segregation of the different crosses and densities. No discrimination among the $\mathrm{F}\left({ }_{3}\right)$ seeds was made, and even the smallest kernels were accepted if they had endosperm. To randomize the samples, the seeds were taken in groups of about ten spiklets from different points of the bags.

\section{General for the growing conditions}

Ca. $400 \mathrm{~kg} / \mathrm{ha}$ of a $15-15-15$ fertilizer was drilled yearly at a depth of $8 \mathrm{~cm}$, crosswise to the plant rows. All the plots were weeded by hand. No herbicide or pesticide was applied. 


\section{Cytology}

Acetic ethanol $(1: 3)$ was used as the fixative. Temporary aceto -orcein squash slides were made.

\section{Statistics}

The following tests were applied to estimate the probability (P) values: Goodness of fit, heterogeneity, hierarchal heterogeneity, and $\chi^{2}$ test for independent samples $\left(\chi^{2}\right)$; Kolmogorov-Smirnov two -sample test (D); Fisher exact probability test; Wilcoxon's two-sample rank test (T); and Student's test $(\mathrm{t})$. When there was a great difference between the samples, the $P$ value was estimated by the nominal measurement.

The estimates for dominance (DOM) were determined according to Hayman's formula (Povilaitis 1968). If the value for DOM is over +100 , it indicates the presence of positive heterosis, if under -100 , negative hetrosis, with the $F_{1}$ falling outside the parental range.

\section{Results}

1. Characteristics of gig mutant and $\mathrm{F}_{\mathbf{1}}$ plants

The five $\mathrm{F}_{1}$ plants grown in 1971 unexpectedly exhibited positive heterosis of yield. The mean kernel number per plant was 645.8 (DOM $=+993$ ), while the standard Hannes gave 118.2 kernels, and HA 68-2 tillered heavily, and did not produce any kernel during the season. All the differences of the small five plant samples were significant $\left(T=0 ; n_{1}=n_{2}=5 ; P=.004\right)$.

The difficulties in obtaining hybrid seed were evident again in 1972. The seven seeds obtained were grown in the dry summer of 1973 . Some morphologic characteristics and grain production of HA 68-2, Hannes-1, and their $\mathrm{F}_{1}$ hybrid were studied. The results are given in Table1.

The robust stature of the (gig) plants, visible in Figs. 1 and 3, is revealed by many of the measurements made. When the (gig) plants are grown sparsely, as in the present case, the height is not remarkable, unlike that in denser conditions (Fig. 1). All the other characteristics except the number of fertile spiklets, the length of lemma, and the main stem height of HA $68-2$, differed highly significantly from those of Hannes-1. The $(\mathrm{gig})$ plants head some $30-$ 40 days later than Hannes. The emergence of the panicle is slow, sometimes remaining partial (Fig. 3), and responds to different environmental factors, as became evident in the pot experiment (Table 2: characterized as the sheetless peduncle). The topmost spiklets of HA 68-2 are usually drooping (Fig. 3). The mutant is very late in Finland and consequently never reaches maturity.

In the pot trial, the heading time was quite different between the genotypes and within the HA 68-2 (Table 2). Lacking the assumptions of anovar, the dates were not analyzed, though many of the differences seem to be significant. The treatments also affected the promptness of the panicle emergence as measured by the sheetless peduncle four months after showing. In addition, there seems to be no clear association between the heading time and the peduncle 
Table 1. Characters of HA $68-2$, Hannes line 1, and their $F_{1}$ grown at density of $30 \times 30 \mathrm{~cm}$ in 1973 . (1)

\begin{tabular}{|c|c|c|c|c|c|c|c|c|}
\hline \multirow[b]{2}{*}{$\begin{array}{l}\text { Plant items } \\
\text { and their } \\
\text { comparisons }\end{array}$} & \multirow[b]{2}{*}{$\begin{array}{c}\text { Growth } \\
\text { period } \\
\text { (days) } \\
(2) \\
\end{array}$} & \multirow[b]{2}{*}{$\begin{array}{c}\text { Number of } \\
\text { shoots } \\
\text { with } \\
\text { panicle }\end{array}$} & \multirow[b]{2}{*}{$\begin{array}{l}\text { Number of } \\
\text { shoots } \\
\text { without } \\
\text { panicle } \\
\text { (3) }\end{array}$} & \multirow[b]{2}{*}{$\begin{array}{l}\text { Height } \\
(\mathrm{cm}) \\
(4)\end{array}$} & \multirow[b]{2}{*}{$\begin{array}{c}\text { Culm } \\
\text { diameter } \\
(\mathrm{mm}) \\
(5)\end{array}$} & \multirow[b]{2}{*}{$\begin{array}{c}\text { Number } \\
\text { of } \\
\text { nodes } \\
(6)\end{array}$} & \multicolumn{2}{|r|}{ M a i n } \\
\hline & & & & & & & $\begin{array}{l}\text { Leaf } \\
\text { width } \\
(\mathrm{mm}) \\
(7)\end{array}$ & $\begin{array}{c}\text { Length of } \\
\text { ligula } \\
(\mathrm{mm}) \\
(8)\end{array}$ \\
\hline HA $68-2 \ldots \ldots \ldots \ldots \ldots$ & 115 & 2.70 & 11.65 & 101.95 & 5.89 & 6.63 & 18.37 & 4.49 \\
\hline & & 0.38 & 1.67 & 4.11 & 0.15 & $(6-8)$ & 0.85 & 0.13 \\
\hline $\mathrm{F}_{1}-\mathrm{HA} \quad 68-2 \ldots \ldots \ldots$ & & $* * *$ & $* * *$ & & $* * *$ & $* * *$ & $* * *$ & \\
\hline 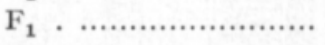 & 85 & 6.00 & 1.29 & 94.79 & 4.40 & 3.00 & 11.80 & 4.27 \\
\hline & & 0.53 & 0.37 & 3.44 & 0.07 & (no range) & 0.38 & 0.08 \\
\hline $\mathrm{F}_{1}-$ Hannes $\quad \ldots \ldots \ldots \ldots . . .$. & & & & & $* * *$ & & * & $* * *$ \\
\hline Hannes .................... & 85 & 6.47 & 1.63 & 89.71 & 3.44 & 2.68 & 10.47 & 3.67 \\
\hline & & 0.57 & 0.36 & 2.04 & 0.08 & $(2-3)$ & 0.39 & 0.11 \\
\hline Hannes-HA $68-2 \ldots$ & & $* * *$ & $* * *$ & $*$ & $* * *$ & $* * *$ & $* * *$ & $* * *$ \\
\hline $\begin{array}{l}\text { DOM } \\
F_{1} \text { as per cent of }\end{array}$ & & +75 & -107 & -17 & -22 & -84 & -66 & +46 \\
\hline Hannes ... ............ & & $92.7 \%$ & $79.1 \%$ & $105.7 \%$ & $127.9 \%$ & $111.9 \%$ & $112.7 \%$ & $116.3 \%$ \\
\hline
\end{tabular}

1 The mean and below it the standard error is given if not otherwise stated.

2 After this period the plants were pulled up by the roots, and allowed to dry in a room for three weeks before the measurements.

3 Height over $10 \mathrm{~cm}$.

4 From the soil surface to the base of the top spiklet (accuracy $0.5 \mathrm{~cm}$ ).

5 Measured at the depression just below the node nearest the middle of the culm. Recorded as the mean of the crosswise measurements (accuracy $0.1 \mathrm{~mm}$ ).

6 The range given in the parenthesis.

7 The greatest width of the second leaf from the top (accuracy $0.1 \mathrm{~mm}$ ).

8 At the base of the second leaf from the top (accuracy $0.1 \mathrm{~mm}$ ).

9 On the adaxial surface of the second leaf from the top. Samples were scratched from parts near the midrib ca. $1 \mathrm{~cm}$ away from the ligula. Mounted with lactic acid warming slightly. Five (from HA 68-2 and Hannes) or ten (from $\mathrm{F}_{1}$ plants) measurements were recorded per leaf at the magn. $500 \times$ (accuracy $1 \mu \mathrm{m})$.

10 The lowest florets in ten topmost spiklets (accuracy $0.1 \mathrm{~mm}$ ).

11 The lowest florets of the spiklets classified according to the maximum appearance found as follows: $1=$ none visible to the eye; $2=$ short hairs; $3=$ numerous, long hairs.

12 The weight of the unhulled kernels dried at the room temperature (accuracy $10 \mathrm{mg}$ ).

The significance was estimated with $t$, except for 'number of nodes', 'number of days to top spiklet yellowing' involving HA 68-2, and 'basal pubescence', to which KolmogorovSmirnov or Fisher exact $\mathrm{P}$ test were applied.

elongation of HA 68-2. The modificants of the HA 68-2 most resembling the non-mutant phenotype arose at the low water level, and the most extreme mutant types with a poor panicle emergence under the higher nitrogen level.

The HA 68-2 is many-noded. The number of nodes depends on seasonal and other environmental conditions (Fig. 4 \& Tables $3 \& 4$ ). All the treatments affected more the node number pattern of HA 68-2 than that of Hannes which was influenced highly significantly only by the soil type. Thus, the gig/gig 


\begin{tabular}{|c|c|c|c|c|c|c|c|c|c|}
\hline \multicolumn{7}{|l|}{ shoot } & \multicolumn{3}{|c|}{ All shoots. } \\
\hline $\begin{array}{l}\text { Length of } \\
\text { stoma } \\
\mu \mathrm{m} \\
(9)\end{array}$ & $\begin{array}{l}\text { Number of } \\
\text { days to } \\
\text { emergency of } \\
\text { top spiklet }\end{array}$ & $\begin{array}{l}\text { Number of } \\
\text { days to top } \\
\text { spiklets } \\
\text { yellowing }\end{array}$ & $\begin{array}{c}\text { Number of } \\
\text { fertile } \\
\text { spiklet }\end{array}$ & $\begin{array}{l}\text { Number of } \\
\text { spiklets } \\
\text { total }\end{array}$ & $\begin{array}{l}\text { Length } \\
\text { of lem ma } \\
(\mathrm{mm}) \\
(10)\end{array}$ & $\begin{array}{c}\text { Basal } \\
\text { pudescence } \\
\text { (rank) } \\
\text { (11) }\end{array}$ & $\begin{array}{l}\text { Number } \\
\text { of } \\
\text { kernels }\end{array}$ & $\begin{array}{l}\text { Yield } \\
(\mathrm{g}) \\
(12)\end{array}$ & $\begin{array}{l}\text { Mean } \\
\text { kernel } \\
\text { weight } \\
(\mathrm{mg})\end{array}$ \\
\hline 55.37 & 77.00 & $>115$ & 23.32 & 115.16 & 18.12 & 3 & 48.00 & $(1.11$ & \\
\hline 0.57 & 1.66 & & 6.56 & 12.60 & 1.07 & & 14.17 & $0.34)$ & \\
\hline$* *$ & $* * *$ & $* * *$ & $* * *$ & $*$ & & $* * *$ & $* * *$ & $* * *$ & \\
\hline 62.47 & 46.43 & 68.14 & 73.00 & 83.43 & 17.88 & 2 & 585.00 & 17.74 & 30.32 \\
\hline 0.68 & 0.43 & 1.12 & 6.55 & 4.08 & 0.79 & & 67.60 & 2.61 & \\
\hline & $* * *$ & & $* * *$ & $* * *$ & & $* * *$ & $* * *$ & $* *$ & \\
\hline 66.25 & 43.32 & 67.16 & 28.68 & 31.05 & 17.61 & 1 or 2 & 233.32 & 8.19 & 35.08 \\
\hline 0.77 & 0.62 & 0.91 & 2.49 & 2.81 & 0.67 & & 22.47 & 0.82 & \\
\hline$* * *$ & $* * *$ & $* * *$ & & $* * *$ & & $* * *$ & $* * *$ & $* * *$ & \\
\hline+30 & -82 & $<-96$ & +1754 & +25 & +6 & & $\div 480$ & $(+370)$ & \\
\hline $94.3 \%$ & $107.2 \%$ & $101.5 \%$ & $254.5 \%$ & $268.7 \%$ & $101.5 \%$ & & $250.7 \%$ & $216.6 \%$ & $86.4 \%$ \\
\hline
\end{tabular}

constitution seems to be more sensitive to external factors than the (Gig) plants. Up to a height of $44 \mathrm{~cm}$, the lower nodes have been found to put out secondary rootlets. The fruitless tillering of the mutant is quite obvious (Table 1), but is evidently greatly dependent on the environment, in particular the plant density.

During warm weather, a fragrant gas transpires from the mutant plants. The smell is much fainter in a single plant of $\mathrm{F}_{1}$ or Hannes and only appears at the early vegetative period, it may even be quite inconspicuous. The $F_{1}$ plants were in many of their decisive characteristics similar to Hannes-1 (Table 1). A single heterozygous plant is hardly distinguishable from a Hannes plant. Therefore, the mutant may be classified as rescessive. The vegetative development of the $F_{1}$ plants was somewhat slower than that of the Hannes standard, they nevertheless reached maturity at the same time. Yield, kernel number, as well as the number of spiklets per panicle exhibited a significant positive heterosis, the kernel number being $250.7 \%$ of that produced by Hannes-1. The kernel number was again of the same level as that of the $\mathrm{F}_{\mathbf{1}}$ plants grown in $1971(\mathrm{t}=0.443$; d.f. $=10)$. As the $\mathrm{F}_{1}$ plants had a slightly lower number of fertile shoots than Hannes, the most decisive yield component of the heterosis was the kernel number per panicle.

Unexpectedly, the HA 68-2 had smaller stomata than Hannes-1 (Table 1). In general, the stomata of the $\mathrm{F}_{\mathbf{1}}$ plants were intermediary and did not differ significantly from those of Hannes-1. This results can be a sign of a generally smaller cell-size in HA $68-2$, though this was not actively studied by other means.

A preliminary study under the $12 / 12 \mathrm{~h}$ photoperiod was performed. This photoperiodic adjustment raised partial gig phenocopies from Hannes. The phenocopies are similarly robust, many-noded, and late. This photoperiod was not, however, inductive for the heading of HA $68-2$. 


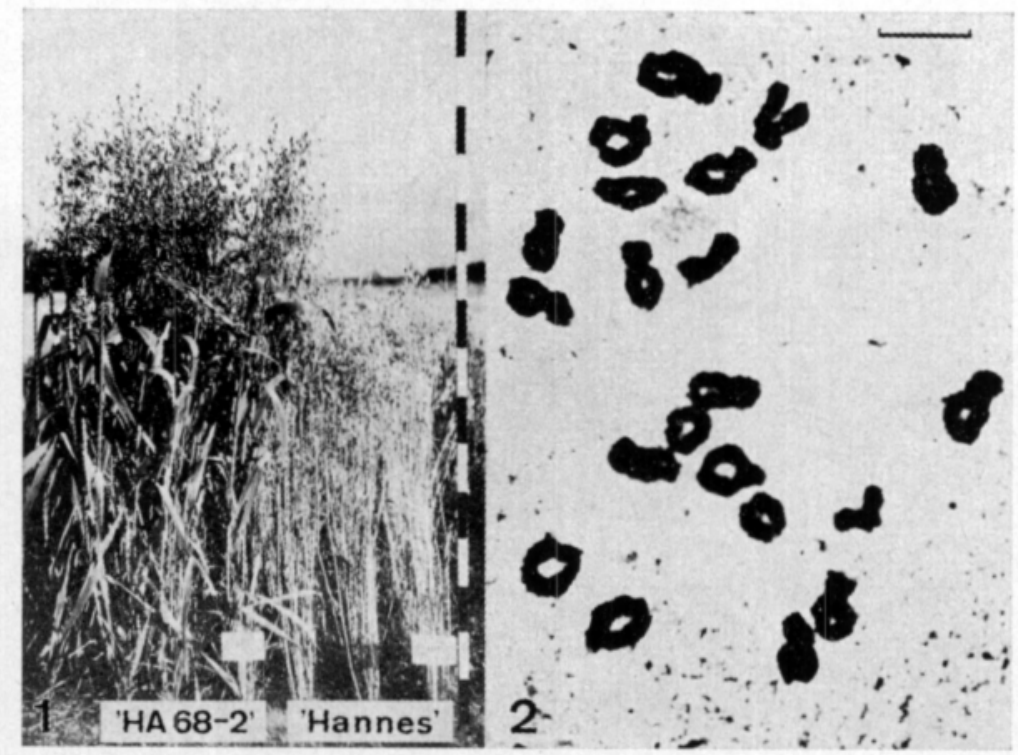

Fig. 1-2. Microplots of HA 68-2 and Hannes photographed 8. IX. 1971, about three weeks after the maturing of Hannes. The mutant has reached only the early milk stage. The row distance is $15 \mathrm{~cm}$. The scale units indicate $10 \mathrm{~cm}$. - Fig. 2. Diakinesis of the $\mathrm{F}_{1}, \mathrm{HA} 68-2$ (ㅇ) $\times$ Hannes-1 $\left(\sigma^{*}\right)$, quite normal in appearance. Scale $10 \mu \mathrm{m}$.

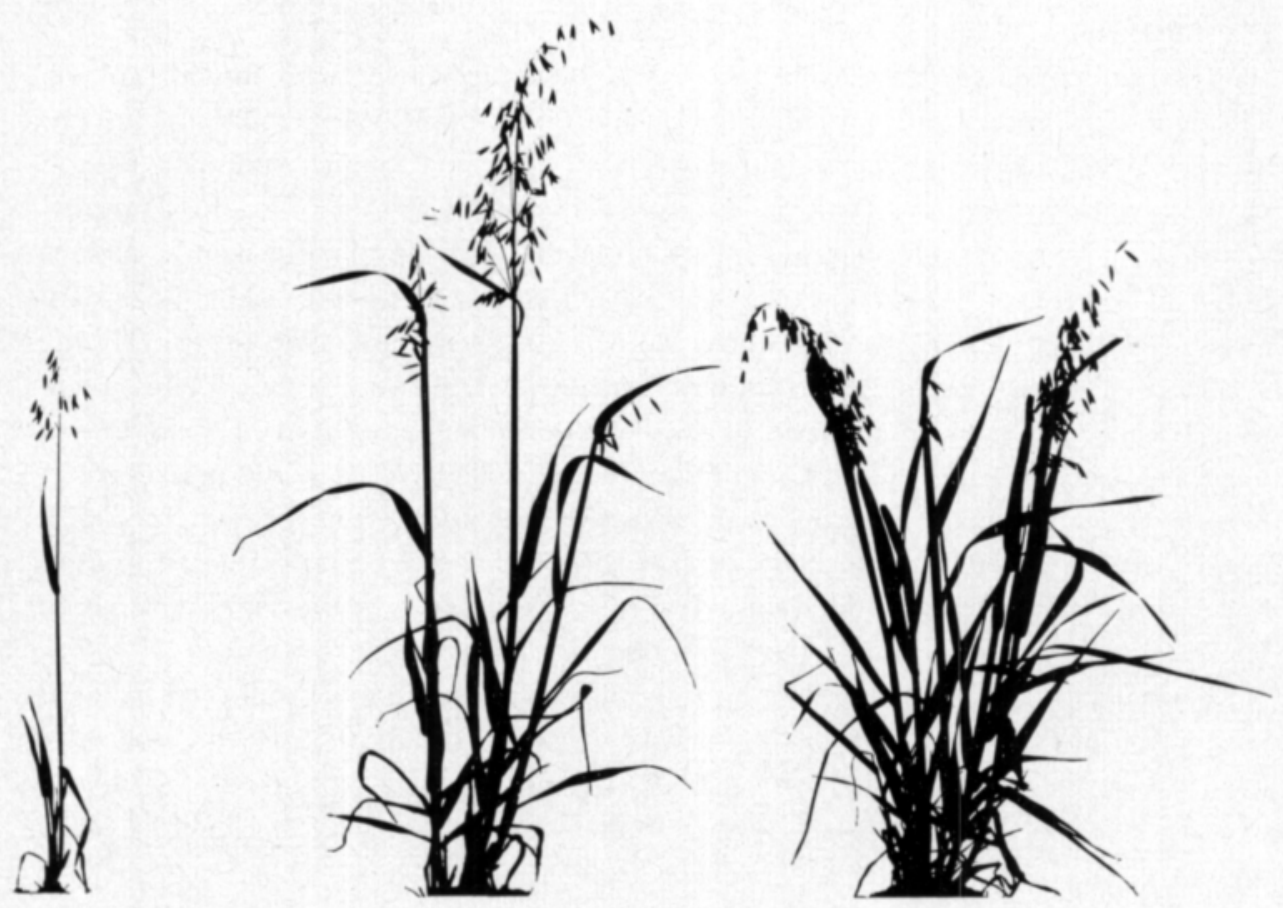

Fig. 3. Silhouettes of oat plants at or shortly after the anthesis. - To the left: Hannes. - In the middle: HA $68-2$ grown at the density of $4 \times 17.5 \mathrm{~cm}$. - To the right: HA $68-2$ grown at the density of $8 \times 25 \mathrm{~cm}$. The tillering is excessive and the appearance of the panicles partial. 
Table 2. The performance of HA 62-2 and Hannes-1 in the pot experiment. Mean and standard error below it are usually stated.

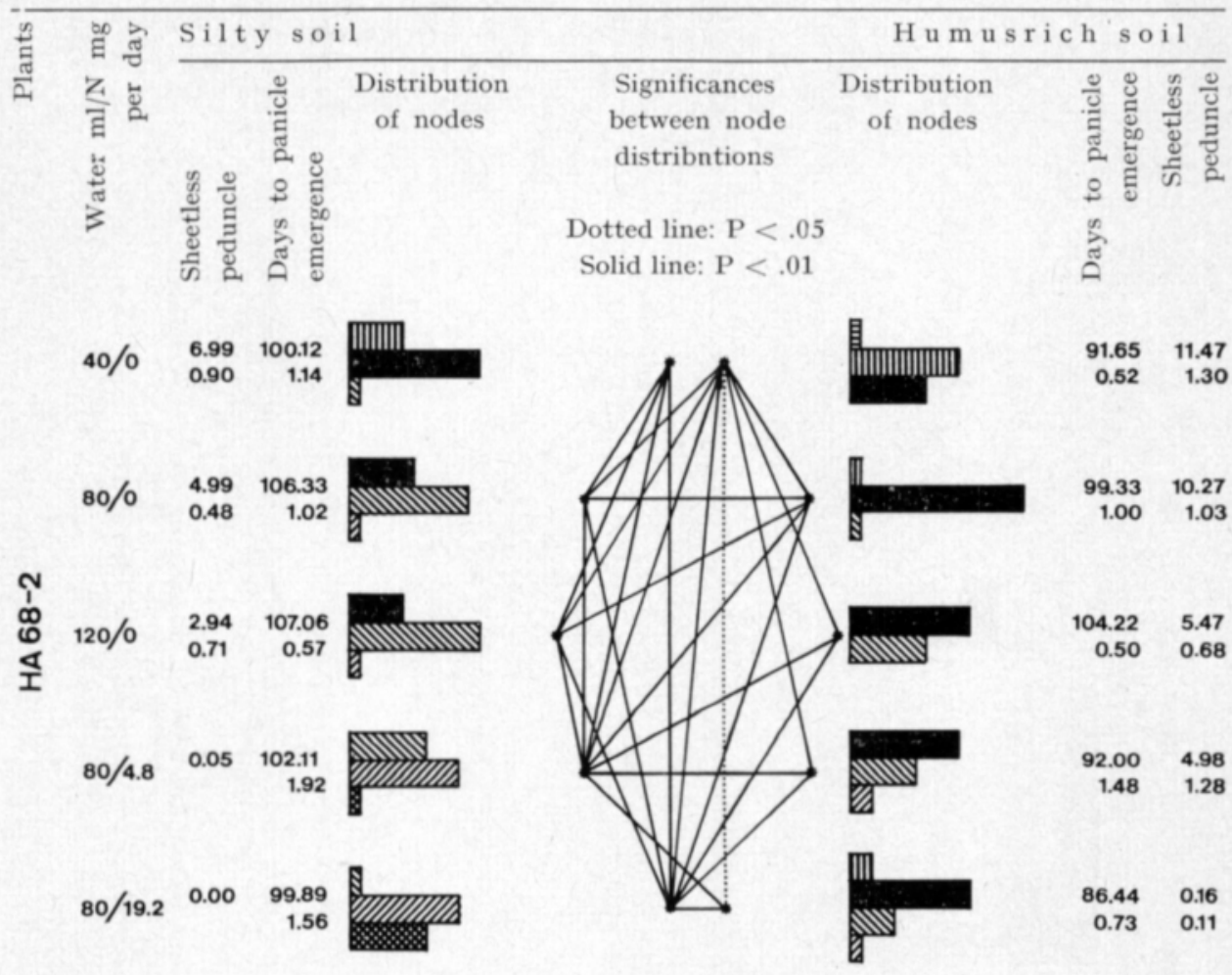

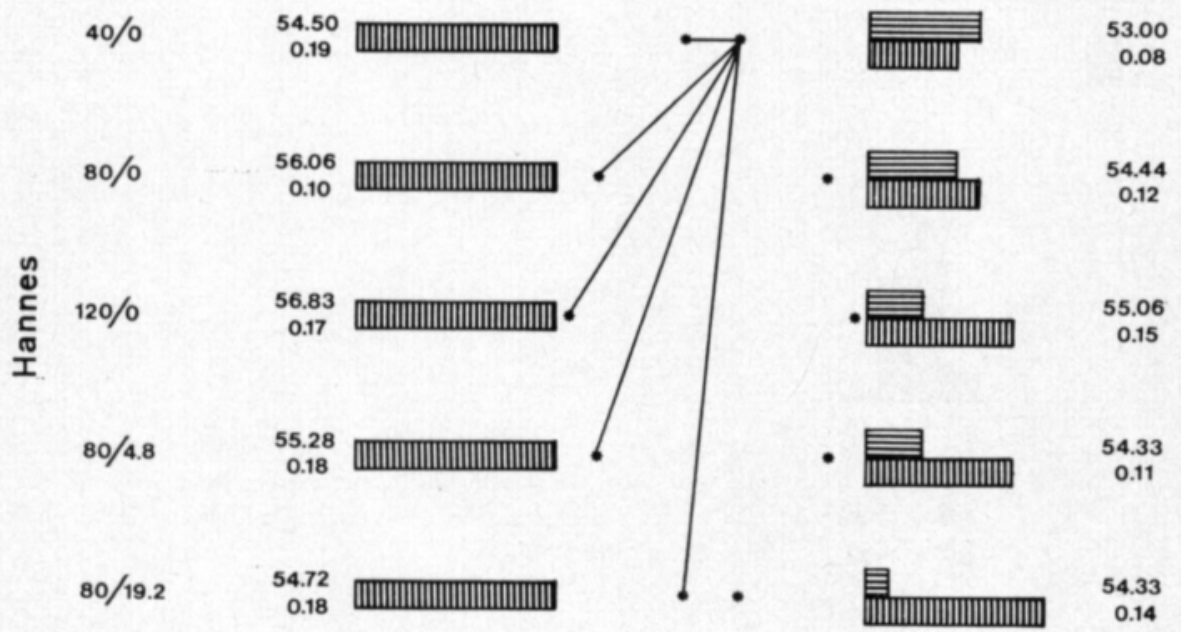

The differences between HA $68-2$ and Hannes were significant $(\mathrm{P}<.01)$, except for the $40 \mathrm{ml}$ water level of HA $68-2$ on the silty soil. It differed significantly $(\mathrm{P}<.05)$ only from the $40 \mathrm{ml}$ water level of Hannes on the silty soil, the other differences being insignificant. 
Table 3. The extent of association between the node number and the genotypes or treatments by the contingency coeficient $\mathrm{C}$. The corresponding distributions are in Table 2 .

\begin{tabular}{lcc}
\hline Genotypes & $\mathrm{C}=0.684 * * *$ & $\left(\chi^{2}=315.843 ;\right.$ d.f. $\left.=5\right)$ \\
\hline & HA $68-2$ & Hannes \\
\hline $\begin{array}{l}\text { Soil types } \\
\text { within genotypes ........... }\end{array}$ & $\left(\chi^{2}=43.751 ;\right.$ d.f. $\left.=4\right)$ & $\mathrm{C}=0.408 * * *$ \\
$\begin{array}{l}\text { Water levels } \\
\text { within genotypes ............ }\end{array}$ & $\left(\chi^{2}=45.593 ;\right.$ d.f. $\left.=4\right)$ & $\left(\chi^{2}=36.000 ;\right.$ d.f. $\left.=1\right)$ \\
$\begin{array}{l}\mathrm{N} \text { levels } \\
\text { within genotypes .......... }\end{array}$ & $\left(\chi^{2}=21.906 ;\right.$ d.f. $\left.=4\right)$ & $\left(\chi^{2}=4.198 ;\right.$ d.f. $\left.=2\right)$ \\
\hline
\end{tabular}

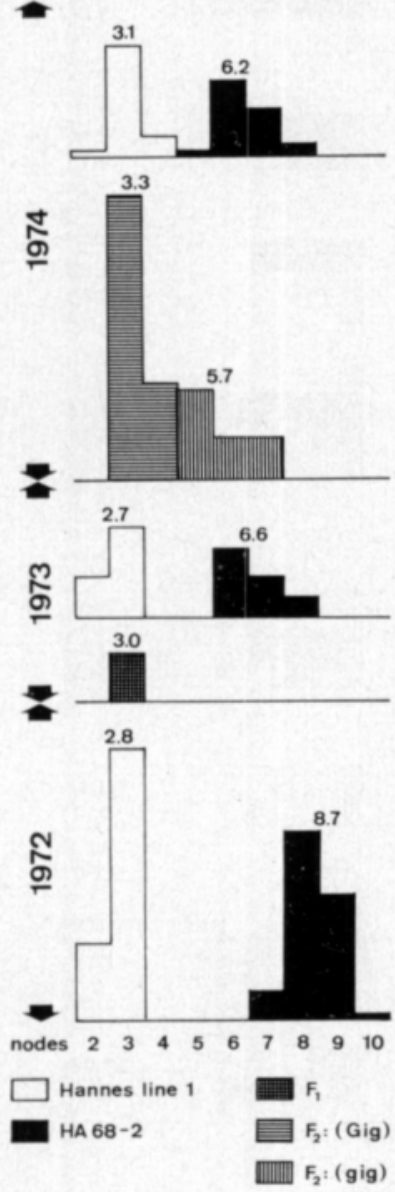

Fig. 4. The number of nodes of the main culm above the soil surface at heading. The means are given at the top of the histograms. The corresponding significances are given in Table 4.

The $F_{1}$ meiosis did not reveal any cytologically observable chromosomal changes, when Hannes-1 was the other parent (Fig. 2). Therefore, HA 68-2 is not of a higher polyploid level than the normal oats, aneuploid, or telosomic.

No normalizing response to the seed vernalization or gibberellins was shown by the mutant. Instead, gibberellins tended to induce one additional node 
Table 4. The significances of the node number distributions of Fig. 4. Estimated by D.

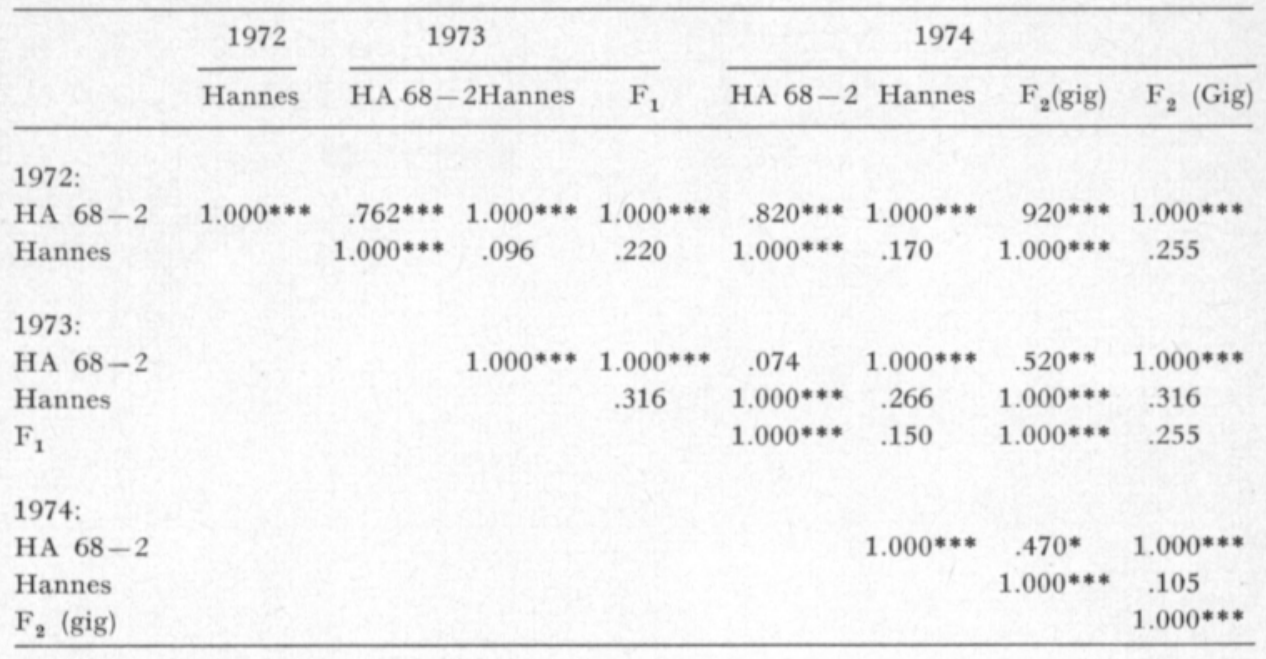

per stem (Table 5). Neither was any genetic complementation by Ustilago evident (Table 6), but as the panicle appearance was delayed, subepidermal stripes of the smut were found in the topmost leaves of the infected mutant plants.

2. $\mathrm{F}_{2}$ segregation

At the time when the (Gig) phenotypes have matured the classification of the mutant is easy. The segregation numbers given in Table 7 fit quite well in the $3: 1$ ratio $(P>.80)$ without any significant heterogeneity between the crosses $(\mathrm{P}>.30)$. Thus the inheritance follows the monofactorial model.

3. $\mathrm{F}_{3}$ segregation of selected fraction

As the (gig) phenotypes of the $\mathrm{F}_{2}$ generation were discarded, the remaining fraction contained the Gig/Gig and Gig/gig genotypes. These are consequently expected to exist in the ratio $1: 2$. Since oat is a self-pollinator, the expected $\mathrm{F}_{3}$ segregation of this fraction would consequently be 5: 1. This assumes, however, that in the $\mathrm{F}_{2}$ generation the number of the germinable seeds produced

Table 5. The effect of gibberellins on the node number of HA 68-2. The significance tested by D.

\begin{tabular}{|c|c|c|c|c|c|c|}
\hline \multirow{2}{*}{ Treatment } & \multirow{2}{*}{$\begin{array}{l}\text { Sample } \\
\text { size }\end{array}$} & \multicolumn{2}{|c|}{ Number of nodes } & \multirow{2}{*}{$\mathrm{GA}_{4}$} & \multirow{2}{*}{$\mathrm{GA}_{7}$} & \multirow{2}{*}{ Control } \\
\hline & & Range & Mode & & & \\
\hline 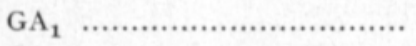 & 46 & $5-8$ & 7 & .035 & .141 & $.408 * *$ \\
\hline 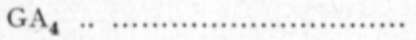 & 47 & $5-8$ & 7 & & .160 & $.373^{* *}$ \\
\hline $\mathrm{GA}_{7} \ldots \ldots \ldots \ldots \ldots \ldots \ldots \ldots \ldots \ldots \ldots \ldots \ldots \ldots \ldots \ldots \ldots$ & 45 & $5-8$ & 7 & & & $.267^{\circ}$ \\
\hline Control .............................. & 45 & $5-8$ & 6 & & & \\
\hline
\end{tabular}


Table 6. The effect of cold vernalization and infection with Ustilago on HA 68-2.

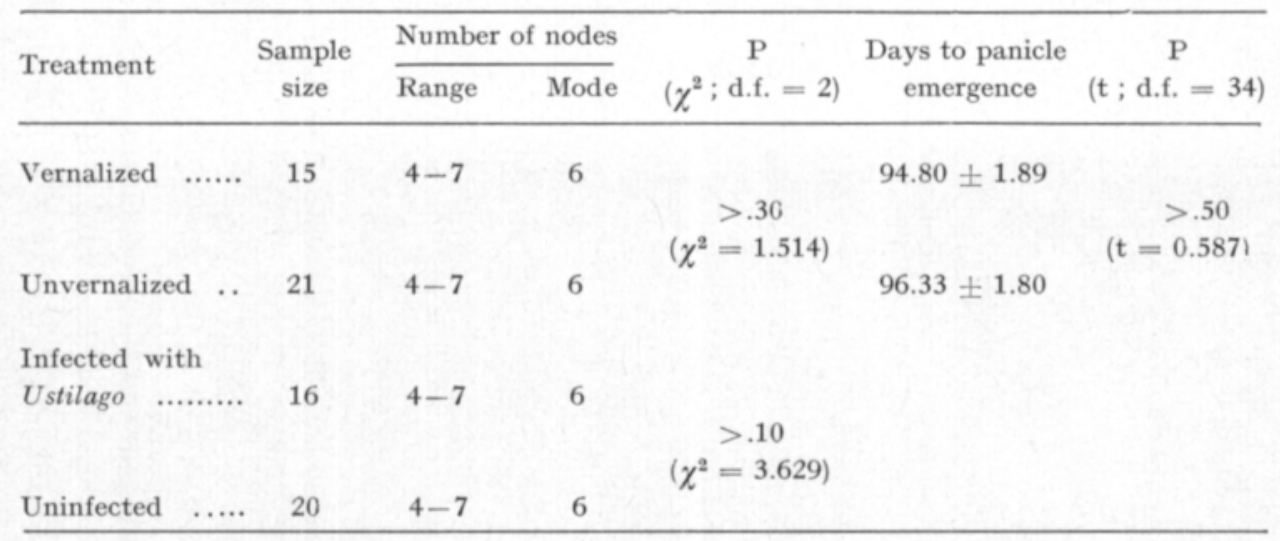

Table 7. The $\mathrm{F}_{2}$ segregation of (Gig) and (gig) phenotypes.

\begin{tabular}{|c|c|c|c|c|}
\hline $\begin{array}{c}\text { Cross } \\
\text { no. }\end{array}$ & $\begin{array}{l}\text { Pollen } \\
\text { parent }\end{array}$ & $\begin{array}{c}\text { Number of } \\
\text { phenotypes } \\
\text { (Gig)/(gig) }\end{array}$ & $\begin{array}{c}\chi^{2} \\
(\text { expected } 3: 1)\end{array}$ & $\mathbf{P}$ \\
\hline 1 & 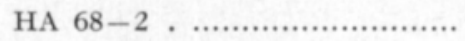 & $308 / 95$ & 0.438 & $>.50$ \\
\hline 2 & 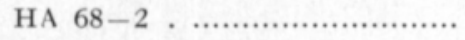 & $396 / 151$ & 1.970 & $>.10$ \\
\hline 3 & Hannes ... ............................. & $183 / 49$ & 1.862 & $>.10$ \\
\hline 4 & 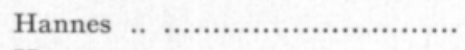 & $299 / 92$ & 0.451 & $>.50$ \\
\hline 5 & Hannes ... ............................ & $122 / 34$ & 0.855 & $>.30$ \\
\hline \multirow[t]{2}{*}{6} & 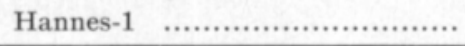 & $904 / 312$ & 0.211 & $>.50$ \\
\hline & $\begin{array}{l}\text { Total } \ldots \ldots \ldots \ldots \ldots \\
\text { Heterogeneity } \chi^{2}=5.838\end{array}$ & $2212 / 733$ & 0.019 & $\begin{array}{l}>.80 \\
>.30\end{array}$ \\
\hline
\end{tabular}

by the Gig/Gig plants is not different from that by the heterozygotes, Gig/gig. A high overdominance of the Gig/gig heterozygotes would lower the 5: 1 ratio. The heterozygotes could hypothetically be expected to be very heterotic in grain production on the basis of the previous results with the $\mathrm{F}_{\mathbf{1}}$ plants.

The segregation of the $\mathrm{F}_{3}$ is presented in Table 8 . As a whole, the result fitted in to the 5:1 ratio $(\mathrm{P}>.10)$. The hierarchal heterogeneity test (Table 9) revealed some influence by the density in which the $F_{2}$ generation was grown $(\mathrm{P}<.05)$. A highly significant heterogeneity was found between the different cross combinations $(\mathrm{P}>.001)$. The cross no. 4, consistently among all the blocks, gave less (gig) plants than was expected $\left(\chi^{2}=14.317 ; \mathrm{P}<.001\right)$. On the other hand, cross no. 3 gave many more (gig) segregants than could be expected on the $5: 1$ basis $\left(\chi^{2}=9.734 ; \mathrm{P}<.01\right)$. In fact, the result of cross no. 3 fitted better in to the $4: 1$ ratio $\left(\chi^{2}=0.027 ; \mathrm{P}>.80\right)$. This ratio might be expected if the heterozygotes of the $\mathrm{F}_{2}$ generation were able to produce twice the number of germinable kernels than was produced by the Gig/Gig homozygotes. The doubled kernel number was approximately of the level produced by the $F_{1}$ hybrids in 1973 . In the present sample, the lowest ratio was found in the offspring of the highest density block. 
Table 8. The $F_{3}$ segregation of the selected fractions.

\begin{tabular}{|c|c|c|c|c|c|}
\hline $\mathrm{F}_{2}$ spacing & $\begin{array}{c}\text { Cross } \\
\text { no. }\end{array}$ & $\begin{array}{c}\text { Number of } \\
\text { phenotypes } \\
\text { (Gig)/(gig) }\end{array}$ & Ratio & $\begin{array}{c}\chi^{2} \\
(\text { expected } 5: 1)\end{array}$ & $\mathrm{P}$ \\
\hline \multirow[t]{6}{*}{$2 \times 10 \mathrm{~cm}$} & 1 & $379 / 96$ & 3.95 & $4.295^{*}$ & $<.05$ \\
\hline & 2 & $396 / 73$ & 5.43 & 0.410 & $>.50$ \\
\hline & 3 & $399 / 99$ & 4.03 & $3.701^{\circ}$ & $>.05$ \\
\hline & 4 & $349 / 51$ & 6.84 & $4.420^{*}$ & $<.05$ \\
\hline & Total & $1523 / 319$ & 4.77 & 0.563 & $>.30$ \\
\hline & Heterogeneity & $=12.826^{* *}$ & & & $<.01$ \\
\hline \multirow[t]{6}{*}{$4 \times 17.5 \mathrm{~cm}$} & 1 & $392 / 79$ & 4.96 & 0.004 & $>.90$ \\
\hline & 2 & $387 / 74$ & 5.23 & 0.125 & $>.70$ \\
\hline & 3 & $348 / 89$ & 3.91 & $4.306^{*}$ & $<.05$ \\
\hline & 4 & $415 / 64$ & 6.48 & $3.768^{\circ}$ & $>.05$ \\
\hline & Total & $1542 / 306$ & 5.04 & 0.016 & $>.80$ \\
\hline & Heterogeneity & $=8.187^{*}$ & & & $<.05$ \\
\hline \multirow[t]{7}{*}{$8 \times 25 \mathrm{~cm}$} & 1 & $401 / 40$ & 10.03 & $18.323^{* * *}$ & $<.001$ \\
\hline & 2 & $429 / 80$ & 5.36 & 0.330 & $>.50$ \\
\hline & 3 & $341 / 81$ & 4.21 & 1.941 & $>.10$ \\
\hline & 4 & $377 / 52$ & 7.25 & $6.382^{*}$ & $<.05$ \\
\hline & Total & $1548 / 253$ & 6.12 & $8.894 * *$ & $<.01$ \\
\hline & Heterogeneity & $=18.082^{* * *}$ & & & $<.001$ \\
\hline & Total & $4613 / 878$ & 5.25 & 1.811 & $>.10$ \\
\hline
\end{tabular}

Table 9. The hierarchal heterogeneity analysis of the segregations of Table 8 .

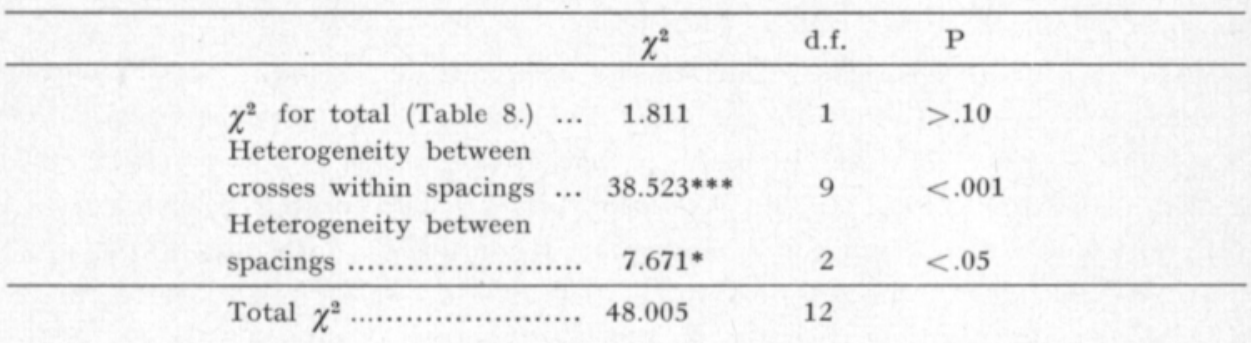

\section{Discussion}

The name gigantic is not applicable to all the characteristics, such as the kernel size. In terms of the length of lemma, the kernel size did not significantly differ from that of Hannes. In the cereals, true gigantic diploid mutants are known in barley, in which all the parts including the kernels are enlarged (Nувом 1954). The lateness and many-noded stems are at least as conspicuous as the larger vegetative parts.

The stomata of the mutant leaf were not gigantic, either, but significantly smaller than those of Hannes. The inconsistency between the stoma size and the somewhat enlarged vegetative parts can be a sign of an increased number of cells per unit in the mutant. 
The number of nodes on the main culm of the mutant was influenced by seasonal and other environmental conditions, while that of the standard, Hannes-1, was only slightly or not at all affected. Ross (1955) also found that the internode number of oats was not influenced by the different years being the least variable morphologic character studied. Thus, the gig/gig genotype is to a considerable extent responsive to seasonal and environmental factors.

HA 68-2 was found to be an euploid like the other studied gigantic oats (Schegalow 1922, Schwanitz and Pirson 1955, Gielo 1969). None of the several oat aneuploids known by now have been reported as exceptionally latematuring and many-noded. Tall, later maturing offtypes are segregated from the Clinton oats, apparently due to the instability of this variety, in which also somatic segregation has been demonstrated (MOREy 1949). An exceptional interaction in an oat cross giving a gigantic offspring was reported by RoTHMAN and Bowman (1963). The plants are in appearance very similar to HA 68-2 (Rothman and Bowman 1963: Figs. 1-3). However, the inheritance of that uncommon case was not stated. Several typical gig mutants were found by Gielo $(1969,1970)$ in irradiated oats.

The poor seed set in crosses prevented study in an adequate form and extent. The reason for the difficulties may have been in the failure to synchronize the flowering of the parental plants. Some sporophytically controlled cross incompatibility may also have been present.

The level of the observed positive heterosis of the number and weight of kernels was high in the $F_{1}$ plants. Likewise, using the spacing of $30 \times 30 \mathrm{~cm}$ or $1 \times 1$ foot, Coffman and Wiebe (1930) and Petr and Frey (1967) in Idaho, found an average yield heterosis of about $20 \%$ over the mean weight of the parents' yield.

The results with cereals regarding the influence of the plant density on the heterosis of grain production per plant are contradictory (see: SEvERSON and Rasmusson 1968, Hayes 1970, YAP and Harvey 1971, Zeven 1972, and Sharma and Reinbergs 1973). As the results are not comparable, due to the different species, genotypes, and experimental conditions, both possibilities must be right. As to oats, the response to the row spacing was found to be markedly affected by the weather (Fотн \& al. 1964). There was some influence on the segregation of the present test by the different densities. Instead, the different crosses were highly significant. It is evident, therefore, that HA $68-2$ and the different Hannes plants used were not isogenic, and that the lack of isogeny in loci other than Gig was at least partly responsible for the observed heterosis. The unisogeny may have been the reason for the slightly different node number of the $\mathrm{F}_{2}$ (gig) segregates and that of $\mathrm{HA} 68-2$ (Fig. 4.)

In his gigantic mutant with a background evidently of a high isogeny, Schegalow (1922) observed in the fraction of the $\mathrm{F}_{3}$ equivalent $19.7 \%$ mutants (expected $1 / 6$ or $16.7 \%$ ). In the following seasons, the proportion of the mutant segregants varied from 17.6 to $21.2 \%$. Heterozygotic advantage could therefore have been present. Lacking the original methods and records his results can not be tested statistically, however. 
In predominantly self-pollinated species, the decay in heterozygosity on the basis of morphology and enzyme pattern was found to be slower at several loci than was expected for the observed amount of outcrossing (JAIN and Allard 1960, Iman and Allard 1965, Jain and Marshall 1967, and Clegg and Allard 1973). The highly inbreeding species of the Festuca microstachys complex were found to be as variable as the species which had some or a total outcrossing as the mode of their reproduction (KAnnenberg and Allard 1967). In Finland, the oats is evidently an almost obligatory self-pollinator, and is hence expected to possess some type of heterozygotic advantage mechanism in maintaining genetic variation.

The changes in allelic frequences which occurred from generation to generation in barley were found to be consistent with selection operating in different ways in the different environmental conditions of different years, or groups of years (Allard and KAHLER 1972). As June, the decisive month for the determination of the crop, was considerably drier and warmer in 1973 than on an average in SE Finland (Ilmatieteen laitos 1973), this type of wether can partly promote the fecundity of the Gig/gig genotypes in the complex of the environment the plants experienced. Additional studies are, however, needed to test the hypothesis that the retention of the gig allele is promoted through the heterozygote advantage, and that the apparently sudden increases at times could arise from previous year's seasonal conditions exceptionally favourable for the heterozygotes.

Acknowledgements. The work was supported by a grant from the Betty Vaaänäsen Rahasto Foundation. To Field Manager T. Huisman (Abbott, S. A., Belgium) I am obliged for the gibberellin samples. 


\section{REFERENCES}

Allard, R. W. \& Kahler, A. L. 1972. Patterns of molecular variation in plant populations. In: Lecam, L. M., Neyman, J. \& Scott, E. L. Proc. 6th Barkeley Symp. Mathem. Statist. Probability, Vol. V: 237. -254.

Clegg, M. T. \& Allard, R. W. 1973. Viability versus fecundity selection in the slender wild oat, Avena barbata L. Science 181: $667-668$.

Coffman, F. A \& Wiebe, G. A. 1930. Hybrid vigor in oats. J. Amer. Soc. Agron. 22: $848-860$.

Foth, H. D., Robertson, L. S. \& Brown, H. M. 1964. Effect of row spacing distance on oat performance. Agron. J. 56: 70-73.

Grelo, S. 1969. Giant-type mutation in oat. Genet. Polon. 10:62-68.

- - 1970. Wlasciwosci niektorych mutantow owsa. Biul. Inst. Hodowli Aklimat. Roslin (1970): 37-44. (An English summary in Genet. Polon. 13:124, and Plant Breed. Abst. 43: abst. 1047.)

Hayes, J. D. 1970. Arable crop breeding. Welsh Plant Breed. Sta., Jubil. Rep. 19191969: 101-142.

Ilmatieteen laitos 1973. Kuukausikatsaus Suomen ilmastoon 67.

Iмaм, A. G. \& Allard, R. W. 1965. Population studies in predominantly self-pollinated species. VI. Genetic variability between and within natural populations of wild oats from different habitats in California. Genetics 51: 49-62.

JAIn, S. K. \& Allard, R. W. 1960. Population studies in predominantly self-pollinated species, I. Evidence for heterozygote advantage in a closed population of barley. Proc. Nat. Acad. Sci. U.S.A. 46: 1371-1377.

- - \& Marshall, D. R. 1967. Population studies in predominantly self-pollinated species. X. Variation in natural population of Avena fatua and A. barbata. Amer. Naturalist 101: 19-33.

Kannenberg, L. W. \& Allard, R. W. 1967. Population studies in predominantly selfpollinated species. VIII. Genetic variability in the Festuca microstachys complex. Evolution 21: 227-240.

Krvı, E. 1968. Ähtärin 'ihmekaura' mielenkiintoinen mutaatio. Ominaisuuksia sensaatiomaisesti liioiteltu. (A newspaper article: 'The wonder oats' at Ähtäri, an interesting mutation. Characters sensationally exaggerated. In Finnish.) Maaseudun Tulevaisuus $52(98): 1,10$.

Morey, D. D. 1949. The extent and causes of variability in Clinton oats. Iowa State Coll. Agric., Res. Bull. 363: 1-44.

Nyвом, N. 1954. Mutation types in barley. Acta Agric. Scand. 4: 430-456.

Petr, F. C. \& Frey, K. J. 1967. Heterosis in oats. Crop Sci. 7: 33-36.

Povilartis, B. 1968. Photoperiodic response and its effects on certain quantitative characters in tobacco. Canad. J. Genet. Cytol. 10:515-522.

Ross, W. M. 1955. Associations of morphological characters and earliness in oats. Agron. J. 47: 453-457.

Rothman, P. G. \& Bowman, D. H. 1963. An observation on hybrid vigor in oats. Crop Sci. 3: 184 .

Schegalow, S. 1922. Das Erscheinen des Gigantismus beim Hager. Z. Indukt. Abstamm. Vererb. 29: 207-208. (A German summary).

Schwanitz, F. \& Pirson, H. 1955. Chromosomengrösse, Zellgrösse und Zellenzahl bei einigen diploiden Gigaspflanzen. Züchter 25: 221-229.

Severson, D. A. \& Rasmusson, D. C. 1968. Performance of barley at four seeding rates. Crop. Sci. 8: 339-341.

Sharma, R. K. \& Reinbergs, E. 1973. Performance of hybrids of barley. Ind. J. Genet. Plant. Breed. 33: 118-123.

YAP, T. C. \& HARVEY, B. L. 1971. Heterosis and combining ability of barley hybrids in densely and widely seeded conditions. Canad. J. Plant. Sci. 51: 115-122.

ZEVEN, A. C. 1972. Plant density effect on expression of heterosis for yield and its components in wheat and $F_{1}$ versus $F_{3}$ yields. Euphytica 21: 468-488.

Zillinsky, F. J. 1959. Monster mutant in oats. Cereal News 4 (2): 7-11.

Ms received August 26, 1975. 


\title{
SELOSTUS
}

\section{Kauran (Avena sativa L.) jättiläismutanttien geneettisiä ja morfologisia ominaisuuksia}

\author{
Hannu AнокаS \\ Yliopiston Perinnöllisyystieteen laitos, P. Rautatiekatu 13, 00100 Helsinki 10
}

Tutkielmassa tarkastellaan yhtä Hannes-kauralajikkeesta eristettyä ns. jättiläismutanttia. Erityisesti harvassa kasvustossa mutantti on leveälehtinen, korreltaan paksu ja runsaasti versova. Se on huomattavasti Hannesta myöhäisempi. Mutantti tulee röyhylle $30-40$ päivää myöhemmin kuin Hannes, eikä se ehdi tuleentua pelto-oloissa. Mutantti on korjuuvaiheessa vasta verson pitenemisasteella ja karsiutuu siten vuosittain pois siemensadosta. Ominaisuus, jossa mutantin ja Hannes-kauran muuntelun ei ole todettu menevän päällekkäin, on korren solmujen lukumäärä. Mutantilla on aina vähintään viisi solmua pääversossaan. Astiakokeella ja kolmen vuoden peltokasvatusten perusteella mutantin on todettu reagoivan voimakkaammin ympäristötekijöihin kuin Hannes-kauran. Kyseessä ei ole syysmuoto kaurasta, koska kasvutapaa ei voitu muuttaa vernalisoimalla siementä.

Mutantin ja Hannes-kauran risteytyksestä mutanttialleeli segregoituu resessiivisen monohybridimallin mukaisesti. Kyseessä ei ole aneuploidiaa tai heksaploidiasta poikkeavaa polyploidiaa. F $F_{1}$-hybridit, joita on saatu syntymään varsin niukasti, ovat olleet erittäin heteroottisia, erityisesti, jos tarkastellaan jyvien tuottoa lukumäärältään. Suppeahkot $\mathrm{F}_{\mathrm{3}}$-segregaatio tulokset sekä muilla itsepölytteisillä kasvilajeilla saadut tulokset tukevat heterotsygoottien paremmuus-hypoteesiä. Heterotsygoottien kohonnut siemenentuottokyky joissakin oloissa, joinakin kasvukausina lienee pääsyynä homotsygoottien mutanttien jatkuvaan uudelleen esiintymiseen kaurakasvustoissa. Mutanttien yleisyydessä on ilmeisesti vaihtelua eri vuosina. Tähän vaihteluun lienee edellisen vuoden tai edellisten vuosien ympäristötekijöillä vaikutuksensa. Mutantteja ilmeisesti esiintyy runsaasti, jos edellinen kasvukausi on suosinut heterotsygootteja. 